\title{
CSPDR8 and CsPDR12, two of the 16 pleiotropic drug resistance genes in cucumber, are transcriptionally regulated by phytohormones and auxin herbicide in roots
}

\author{
M. Migocka • A. Papierniak • A. Warzybok • \\ G. Kłobus
}

Received: 2 May 2011/ Accepted: 5 March 2012/Published online: 25 March 2012

(c) The Author(s) 2012. This article is published with open access at Springerlink.com

\begin{abstract}
There are 15 and 23 members of the pleiotropic drug resistance (PDR) proteins, a subfamily of ATP-binding cassette (ABC) transporters, in Arabidopsis thaliana and Oryza sativa, respectively. Until recently, only a few members of Arabidopsis thaliana PDRs (AtPDRs) had been characterized in detail but growing reports indicate that proteins of this family may participate in growth regulator-mediated signaling and phytohormone transport. The profile of Oryza sativa PDRs (OSPDRs) expression in response to different stimuli also suggests that some rice PDRs are associated with a phytohormone-mediated response to environmental changes. Due to the lack of full genome resources, only individual members of PDRs in other plants (Nicotiana, Oryza, Glycine or Spirodela) have been studied. We have previously cloned two full cDNA sequences encoding for cucumber homologs of Arabidopsis PDR8 and PDR12. Here, we present the genomic organization of 16 cucumber PDRs and the phylogeny of the predicted Cucumis sativus PDR (CsPDR) proteins. Further analysis of $C S P D R 8$ and $C S P D R 12$ reveal that these cucumber genes are constitutively expressed mainly in roots of young seedlings and flowering plants (CsPDR8 and $C s P D R 12)$, and in flowers (CsPDR12). In roots, the transcript of $C s P D R 8$ decreased in response to $\mathrm{ABA}$ and
\end{abstract}

M. Migocka $(\varangle) \cdot$ A. Papierniak · A. Warzybok · G. Kłobus Department of Plant Physiology, Institute of Plant Biology, Wroclaw University, Kanonia 6/8, 50-328 Wroclaw, Poland e-mail: mmigocka@biol.uni.wroc.pl

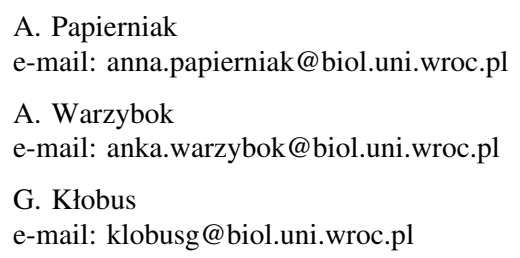

markedly raised in the presence of ACC, salicylic acid or jasmonic acid. In comparison, the expression of CSPDR 12 was not affected by ACC and significantly increased upon the addition of jasmonic acid, salicylic acid, 2,4-D, kinetin or ABA to the growth media. These data suggest that CsPDR8 and CsPDR12 may be involved in a phytohormone-mediated response of plants to different stimuli by sharing different signaling pathways.

Keywords PDR (Pleiotropic drug resistance proteins) . Growth regulators - Phytohormones - Cucumis sativus . Gene expression

$\begin{array}{ll}\text { Abbreviations } \\ \text { ACC } & \text { 1-AminoCyclopropane-1-Carboxylic acid } \\ \text { IAA } & \text { Indole-3-Acetic Acid } \\ \text { ABA } & \text { Abscisic Acid } \\ \text { SA } & \text { Salicylic Acid } \\ \text { JA } & \text { Jasmonic Acid } \\ \text { GA } & \text { Gibberellic Acid } \\ \text { RACE-PCR } & \text { Rapid Amplification of cDNA Ends }\end{array}$

\section{Introduction}

In plants, $\mathrm{ABC}$ transporters constitute a large family of proteins exhibiting ATP hydrolyzing activity associated with the presence of the conservative ATP-binding cassette (ABC) domain. The family comprises different subfamilies separated according to the distinct order of their cytoplasmic and membrane-spanning domains. The full-size transporters contain two ABC (NBD) domains that can be differentially organized in relation to transmembrane 
domains (TMDs) of the proteins. They can be subdivided into three families with the following NBD-TMD composition: (TMD-NBD) $)_{2}$ in multidrug resistance proteins MDR/ABCB, TMD-(TMD-NBD) $)_{2}$ in multidrug resistanceassociated proteins $\mathrm{MRP} / \mathrm{ABCC}$ and (NBD-TMD) $)_{2}$ in pleiotropic drug resistance proteins PDR/ABCG (Crouzet et al. 2006). The half-size ABC proteins contain one TMD domain followed by one ABC domain (TAP, ATH, PMP and ATP subfamilies) with the exception of white-brown complexes (WBC), showing an ABC domain followed by TMD (Sanchez-Fernandez et al. 2001).

Of all the ABC subfamilies, PDR transporters have recently received particular attention since they have been found in plants and fungi but not in animal or prokaryote species. Besides PDRs, only WBC proteins show reverse topology of NBD and TMD domains, so a specific relation between the two subfamilies was somewhat expected. Indeed, sequence analyses of yeast and plant PDRs suggest that PDRs arose by duplication of genes encoding for the half-sized WBC proteins (Dassa and Bouige 2001; Crouzet et al. 2006). They also revealed that the diversity of the PDR family within yeast and plants appeared after the separation of fungi and plant ancestors; therefore, the individual yeast and plant PDR homologs can fulfill different functions (Crouzet et al. 2006). Detailed functional characterization of many of the yeast PDRs revealed that the proteins confer resistance to large number of diverse toxic compounds, including fungicides, herbicides, pesticides, antibiotics and detergents (Crouzet et al. 2006). Hence, yeast PDRs are now regarded as proteins involved predominantly in cell detoxification and cell resistance (Bauer et al. 1999; Rogers et al. 2001). Until recently, it was assumed that plant PDRs are also involved in the cell response to abiotic and biotic stress. Arabidopsis thaliana contains 15 genes encoding members of the PDR family but only a few have been characterized in detail (Table 1). Recently, growing reports reveal that plant PDR proteins might be important not only for the efflux of toxic and harmful compounds from the cell but also for the proper trafficking of the crucial signaling molecules, including hormones that are essential for the regulation of plant growth, development and response to environmental stimuli. It has been shown that AtPDR12/AtABCG40 mediates the uptake of phytohormone ABA in guard cells and other types of plant cells, contributing to the timely closure of stomata in response to drought stress, normal seed germination and lateral root development (Kang et al. 2010). Other plant PDRs, AtPDR9/AtABCG37 and its homolog AtPDR8/AtABCG36 transport a range of synthetic auxinic compounds as well as the endogenous auxin precursor indole-3-butyric acid (IBA) out of the cells
(Strader and Bartel 2009; Růžička et al. 2010). In addition, transcriptional profiles of $P D R$ genes in rice reveal that the expression of plant PDRs is significantly induced by jasmonates, salicylic acid and ABA (Moons 2008; Table 1). Also the expression of soybean homolog of AtPDR12/AtABCG40, GmPDR12, is rapidly induced by salicylic acid and methyl jasmonates (Eichhorn et al. 2006).

Altogether, the data indicate a rather novel and significant role for plant PDR proteins in the transport and homeostasis of plant growth regulators and suggest a possible connection between the PDRs and jasmonates and salicylic acid in the plant response to pathogens. The questions arise whether PDR proteins contribute to the signaling pathways induced by other phytohormones essential for the proper function of plant cells and whether PDR proteins in other plants are functionally similar to their Arabidopsis homologs. The availability of $P D R$ sequences in other plants is still limited though, due to the lack of full genomic resources.

In this study, we have identified and analyzed the expression profile of two cucumber genes, PDR 8 and $P D R 12$, in different organs at two stages of plant development and under various plant growth regulators. We also present the molecular and phylogenetic characterization of CSPDR8, CSPDR 12 and 14 other cucumber PDR homologs of AtPDRs that have been identified through investigation of the recently sequenced cucumber genome (Huang et al. 2009).

\section{Materials and methods}

\section{Plant material}

Cucumber plants (Cucumis sativus, var. Krak) were grown hydroponically on 3-fold diluted Hoagland solution, $\mathrm{pH}$ 6.0, as described earlier (Migocka and Papierniak 2010). The nutrient solution was filter-sterilized, permanently aerated and exchanged twice a week. For the assays of organ expression analyses, roots, hypocotyls or stems, cotyledons, leaves, flowers and fruits were collected after 1 week or 8 weeks of plants cultivation. For the assays including short-term treatment of plants with plant growth regulators, 7-day-old seedlings were transferred on the fresh nutrient solutions containing ABA, IAA, 2,4-D, kinetin, salicylic acid, $\mathrm{GA}_{3}, \mathrm{ACC}$ or jasmonic acid and kept for $4 \mathrm{~h}$. The final concentrations of each regulator are given in the figure captions. For each treatment, four root samples of $50 \mathrm{mg}$ from four different plants were taken for RNA extraction and immediately frozen in liquid nitrogen before storage at $-80{ }^{\circ} \mathrm{C}$. 
Table 1 The properties of so far characterized plant PDR genes and/or proteins

\begin{tabular}{|c|c|c|c|c|}
\hline PDR gene & Species & $\begin{array}{l}\text { The responses to phytohormones, growth regulators } \\
\text { and other stimuli }\end{array}$ & $\begin{array}{l}\text { Tissue } \\
\text { expression }\end{array}$ & References \\
\hline AtPDR6 & $\begin{array}{l}\text { Arabidopsis } \\
\text { thaliana }\end{array}$ & Biotic stress, hormones stress (SA and MJ) & Root & Trombik et al. (2008) \\
\hline AtPDR8 & $\begin{array}{l}\text { Arabidopsis } \\
\text { thaliana }\end{array}$ & $\begin{array}{l}\text { Response to pathogen infection, auxin precursor-IBA } \\
\text { Detoxification of metals }(\mathrm{Cd} \text { and } \mathrm{Pb})\end{array}$ & Root & $\begin{array}{l}\text { Stein et al. (2006), Kobae et al. } \\
\text { (2006), Kim et al. (2007) }\end{array}$ \\
\hline$A t P D R 9$ & $\begin{array}{l}\text { Arabidopsis } \\
\text { thaliana }\end{array}$ & Transmembrane movement of IAA, 2.4-D & Root & Ito and Gray (2006) \\
\hline AtPDR11 & $\begin{array}{l}\text { Arabidopsis } \\
\text { thaliana }\end{array}$ & Biotic stress and hormones stress (SA and MJ) & $\begin{array}{l}\text { Root, flowers } \\
\text { (carpel, } \\
\text { ovary) }\end{array}$ & Trombik et al. (2008) \\
\hline AtPDR12 & $\begin{array}{l}\text { Arabidopsis } \\
\text { thaliana }\end{array}$ & $\begin{array}{l}\text { Response to pathogen infection, hormones stress } \\
\text { (MJ, SA, ethylene) } \\
\mathrm{Cd} \text { and } \mathrm{Pb} \text { transport }\end{array}$ & $\begin{array}{l}\text { Shoot root, } \\
\text { rosette leaf, } \\
\text { cauline leaf }\end{array}$ & $\begin{array}{l}\text { Campbell et al. (2003), Lee et al. } \\
\text { (2005), Trombik et al. (2008) }\end{array}$ \\
\hline OsPDR1 & Oryza sativa & Upregulated by JA & Seeds & Moons (2008) \\
\hline OsPDR2 & Oryza sativa & $\begin{array}{l}\text { Growth regulator responses (JA, SA, ACC, IAA), } \\
\text { redox perturbation (DTT), weak acid stress CA }\end{array}$ & Root & Moons (2008) \\
\hline OsPDR3 & Oryza sativa & $\begin{array}{l}\text { Upregulated by ABA, JA, SA, IAA, BA, weak acid } \\
\text { stress (CA, MA) }\end{array}$ & Root, leaves & Moons (2008) \\
\hline OsPDR5 & Oryza sativa & Upregulated by BA, JA & Panicles & Moons (2008) \\
\hline OsPDR6 & Oryza sativa & Upregulated by $\mathrm{ABA}, \mathrm{CA}$ & Panicles & Moons (2008) \\
\hline OsPDR7 & Oryza sativa & Upregulated by JA, ABA & Seeds, pistil & Moons (2008) \\
\hline OsPDR8 & Oryza sativa & $\begin{array}{l}\text { Upregulation by JA, BA, redox perturbation (DTT, } \\
\text { ASA), weak acid stress (CA LA, MA) }\end{array}$ & Root, leaves & Moons (2008) \\
\hline OsPDR9 & Oryza sativa & $\begin{array}{l}\text { Upregulation by salt stress, hypoxic stress, heavy } \\
\text { metals ( } \mathrm{Zn}, \mathrm{Cd}) \text { and redox perturbations }\left(\mathrm{H}_{2} \mathrm{O}_{2}, \text { DTT }\right. \\
\text { ASA, GSSG, GSH), hormones (IAA, cytokinin, JA) }\end{array}$ & Root, callus & $\begin{array}{l}\text { Moons (2003, 2008) } \\
\text { Crouzet et al. (2006) }\end{array}$ \\
\hline OsPDR12 & Oryza sativa & $\begin{array}{l}\text { Upregulated by JA, BA, redox perturbations }\left(\mathrm{H}_{2} \mathrm{O}_{2} \text {, }\right. \\
\text { ASA) }\end{array}$ & Green leaves & Moons (2008) \\
\hline OsPDR17 & Oryza sativa & $\begin{array}{l}\text { Upregulated by BA, JA, redox perturbations (ASA, } \\
\text { DTT) }\end{array}$ & Root, leaves & Moons (2008) \\
\hline OsPDR2O & Oryza sativa & $\begin{array}{l}\text { Pathogen defense, upregulated by SA, response to } \\
\text { DTT, GSSG GSH-induced redox perturbations }\end{array}$ & Root, leaves & Moons (2008) \\
\hline OsPDR23 & Oryza sativa & Upregulated by $\mathrm{CA}$ & $\begin{array}{l}\text { Panicles, } \\
\text { pistil }\end{array}$ & Moons (2008) \\
\hline $\begin{array}{l}\text { NpPDR1 } \\
\quad(N p A B C 1)\end{array}$ & $\begin{array}{l}\text { Nicotiana } \\
\text { plumbaginifolia }\end{array}$ & $\begin{array}{l}\text { Secretion of a secondary metabolite, biotic and abiotic } \\
\text { stress (sclareol, slareolide, abietic acid) induced by } \\
\text { pathogen and MJ }\end{array}$ & $\begin{array}{l}\text { Root, leaf } \\
\text { trichome, } \\
\text { petal } \\
\text { epidermis }\end{array}$ & $\begin{array}{l}\text { Jasiński et al. (2001), Grec et al. } \\
\text { (2003), Stukkens et al. (2005), } \\
\text { Crouzet et al. (2006), Trombik } \\
\text { et al. (2008) }\end{array}$ \\
\hline NpPDR2 & $\begin{array}{l}\text { Nicotiana } \\
\text { plumbaginifolia }\end{array}$ & Pollination process & Root, flowers & Trombik et al. (2008) \\
\hline NtPDR1 & $\begin{array}{l}\text { Nicotiana } \\
\text { tabacum }\end{array}$ & Pathogen reaction, regulation by SA and JA & ND & $\begin{array}{l}\text { Sosabe et al. (2002), Crouzet et al } \\
\text { (2006) }\end{array}$ \\
\hline NtPDR3 & $\begin{array}{l}\text { Nicotiana } \\
\text { tabacum }\end{array}$ & $\begin{array}{l}\text { Upregulation by Fe deficiency, abiotic stress, } \\
\text { regulation by MJ, SA, NAA }\end{array}$ & ND & $\begin{array}{l}\text { Ducos et al. (2005), Crouzet et al. } \\
\text { (2006) }\end{array}$ \\
\hline TaPDR1 & $\begin{array}{l}\text { Triticum } \\
\text { aestivum }\end{array}$ & Conferring resistance to deoxynivalenol & ND & Shang et al. (2009) \\
\hline GmPDR12 & Glycine max & Regulation by SA and MJ & ND & Eichhorn et al. (2006) \\
\hline SpTUR2 & $\begin{array}{l}\text { Spirodella } \\
\quad \text { polyrrhiza }\end{array}$ & Abiotic stresses: cold, salinity, upregulated by ABA & ND & $\begin{array}{l}\text { Smart and Flaming (1996), } \\
\text { Crouzet et al. (2006) }\end{array}$ \\
\hline
\end{tabular}

$J A$ jasmonic acid, $S A$ salicylic acid, $C A$ citric acid, $A B A$ abscisic acid, $M A$ malic acid, $B A$ 6-benzylaminopurine, $I A A$ indole-3-acetic acid, $A C C$ 1-aminocyclopropane-1-carboxylic acid, DTT dithiothreitol, $G S H$ glutathione, $A S A$ ascorbic acid, $L A$ lactic acid, GA gibberellins, $M J$ methyl jasmonate, 2,4-D (2,4-dichlorophenoxyacetic acid), NAA naphtalene acetic acid 
Semiquantitative and quantitative RT-PCR analysis

Total RNA was isolated from $50 \mathrm{mg}$ of different cucumber tissues using the TRI Reagent (Sigma-Aldrich) following the manufacturer's instruction. To remove contaminating genomic DNA, RNA samples were treated with DNAse I (Fermentas). DNase-treated RNA samples were used for the semiquantitative RT-PCR or reverse transcribed into cDNA for real-time PCR. Semiquantitative RT-PCR was performed using $200 \mathrm{ng}$ of RNA and Titan One Step System (Roche) under the following conditions: $50{ }^{\circ} \mathrm{C}$ for $30 \mathrm{~min}(1 \mathrm{cycle}), 94{ }^{\circ} \mathrm{C}$ for $2 \mathrm{~min}\left(1\right.$ cycle), $94{ }^{\circ} \mathrm{C}$ for $30 \mathrm{~s}$, $57{ }^{\circ} \mathrm{C}$ for $30 \mathrm{~s}$ and $68{ }^{\circ} \mathrm{C}$ for $1 \mathrm{~min}(25$ cycles $)$, and $68{ }^{\circ} \mathrm{C}$ for $10 \mathrm{~min}$ (1 cycle). The reverse transcription of DNAsetreated RNA samples $(2,000 \mathrm{ng})$ was performed using High-Capacity cDNA Reverse Transcription Kit (Applied Biosystem) with random primers following the manufacturer's instructions. Quantitative RT-PCR was performed with a Lightcycler 2.0 system (Roche) using SYBR-Green (A\&A Biotechnology) to detect gene expression abundance, and $E F \propto$ gene was used as an internal control. The cDNA reaction mixture was diluted eight times, and $1 \mu \mathrm{L}$ was used as a template in a $10 \mu \mathrm{L}$ PCR. Amplifications were carried out in $20 \mu \mathrm{L}$ capillaries (Roche) after preincubation at $95{ }^{\circ} \mathrm{C}$ for $30 \mathrm{~s}$, followed by 45 cycles of denaturation at $95{ }^{\circ} \mathrm{C}$ for $10 \mathrm{~s}$, annealing at $57{ }^{\circ} \mathrm{C}$ for $10 \mathrm{~s}$ and extension at $72{ }^{\circ} \mathrm{C}$ for $15 \mathrm{~s}$, with final melting at $65^{\circ} \mathrm{C}$ for $15 \mathrm{~s}$. A negative control without cDNA template was included in the same PCR run for each primer pair. To confirm the specificity of amplification, melting curve analysis was performed allowing to identify putative unspecific PCR products (e.g., primer dimers, reaction mix contamination) and the RT-PCR products were sequenced. Successive dilutions of the sample with the lowest $\mathrm{Cp}$ were used as a standard curve. Amplification efficiency was around 2. For each of the two independent RNA extractions, measurements of gene expression were obtained in triplicate. The list of primers is shown in Table 2.

\section{Identification of full cDNAs of $C s P D R 8$ and $C s P D R 12$}

The partial sequences of CsPDR 8 and $C s P D R 12$ were amplified using primers targeting conservative regions of $P D R$ genes (Table 2). Primers were designed manually basing on the multiple alignment of the known PDR ESTs from different plants. PCRs were run using cDNA synthesized from the total RNA isolated from 1-week-old roots of cucumber seedlings and Marathon polymerase (A\&A Biotechnology). The obtained PCR products were subcloned into pGEM T-Easy (Promega) and sequenced at least four times. For amplification of unknown $3^{\prime}$ and $5^{\prime}$ cDNA ends of CsPDR8 and CsPDR12, RACE-PCRs were performed according to the protocol provided with the GeneRacer Kit (Invitrogen) using $5 \mu \mathrm{g}$ of total RNA isolated from 1-week-old cucumber roots. For the $3^{\prime}$ end, the first strand synthesis reaction was carried out at $50{ }^{\circ} \mathrm{C}$ using GeneRacer OligodT Primer (Table 2). The obtained cDNAs were used in the RACE3'-PCR containing $0.3 \mu \mathrm{M}$
Table 2 The list of primers used in all PCRs

\begin{tabular}{ll}
\hline Primers & Sequences $\left(5^{\prime}-3^{\prime}\right)$ \\
\hline $\begin{array}{l}\text { Primers used in RACE-PCR } \\
\text { GeneRacer Oligo dT Primer }\end{array}$ & \\
GeneRacer $3^{\prime}$ Primer & GCTGTCAACGATACGCTACGTAACGGCATGACAGTG(T) ${ }_{24}$ \\
GeneRacer 5' Primer & CGACTGGAGCACGAGGACACTGA \\
PDR8race3 & GGATGCTATAGTAGGGCTACCAGGAG \\
PDR12race3 & GGAAATGAAATCACAAGGCGTTAC \\
PDR8race5 & AAGGAGTTTCGCTTCATCAACAACC \\
PDR12race5 & CGATGGTCCAACCAACATCTC \\
PDR8race5n & CTCTTGACGCCTTGAGCAGCAGAGGCC \\
PDR12race5n & GCCCACCGGAGATCCCTCGA \\
Primers used in RT-PCR and real-time PCR \\
CsPDR8for & CTTCCCTTCTTGAATCTG \\
CsPDR8rev & ATTTCACCTCTAGGAATGATA \\
CsPDR12for & AGATTCTAGGACTTGAAATCTGTGC \\
CsPDR12rev & TAAGTTGTCGAACTGTCGAATCCTG \\
CsEFfor & ACTTTATCAAGAACATGATTAC \\
CsEFrev & TTCCTTCACAATTTCATCG \\
Primers targeting regions conservative in PDR genes \\
PDRfor
\end{tabular}


GSP primers (PDR8race3 or PDR12race3) and $0.9 \mu \mathrm{M}$ GeneRacer $3^{\prime}$ Primer (Table 2). For the $5^{\prime}$ end, the RNA was ligated to GeneRacer RNA Oligo Sequence and reverse transcribed using GSP primers: PDR8race5 or PDR12race5 (Table 2). The obtained cDNAs were used in the RACE5'-PCR containing $0.3 \mu \mathrm{M}$ GSP nested primers (PDR8race5n or PDR12race5n) and $0.9 \mu \mathrm{M}$ GeneRacer $5^{\prime}$ Primer (Table 2). All PCRs contained $1 \mathrm{U}$ of Marathon polymerase (A\&A Biotechnology), 1× Marathon amplification buffer and dNTP solution $(0.3 \mu \mathrm{M}$ each). The RACE-PCR conditions were as follows: $94{ }^{\circ} \mathrm{C}$ for $2 \mathrm{~min}$, followed by 5 cycles of $94{ }^{\circ} \mathrm{C}$ for $30 \mathrm{~s}$ and $72{ }^{\circ} \mathrm{C}$ for $1 \mathrm{~min} / 1 \mathrm{kB}$ cDNA, followed by 5 cycles of $94{ }^{\circ} \mathrm{C}$ for $30 \mathrm{~s}$ and $70{ }^{\circ} \mathrm{C}$ for $1 \mathrm{~min} / 1 \mathrm{kB}$ cDNA, followed by 25 cycles of $94{ }^{\circ} \mathrm{C}$ for $30 \mathrm{~s}, 65-68{ }^{\circ} \mathrm{C}$ for $30 \mathrm{~s}$ and $72{ }^{\circ} \mathrm{C}$ for $1 \mathrm{~min} /$ $1 \mathrm{kB}$ cDNA with final extension at $72{ }^{\circ} \mathrm{C}$ for $10 \mathrm{~min}$. In all cases, the PCR products obtained were cloned into TOPO vector (Invitrogen) and sequenced (at least three times each). Full cDNAs were submitted to GenBank.

Database searching and sequence analyses

The complete genomic sequence from cucumber has recently been made available to the public in GenBank with accession code ACHR01000000 (Huang et al. 2009). NCBI database (whole-genome shotgun reads) was used for Blastn searches of cucumber sequences with homology to the previously annotated Arabidopsis thaliana PDR sequences. Full cDNAs as well as the protein sequences encoded by the newly identified cucumber PDRs were generated using FGENESH (Salamov and Solovyev 2000). All protein alignments were performed using ClustalW, and the phylogenetic tree was generated using MEGA5.0 software (Tamura et al. 2011) with bootstraps 1,000. The prediction of subcellular localization was performed using ProtComp v8.0 (softberry.com), whereas TMHMM method (Sonnhammer et al. 1998), based on a hidden Markov model (HMM) approach, was applied to predict membrane topology of two CsPDR proteins.

\section{Accession numbers}

Sequence data from this article can be found in the GenBank/ EMBL databases under the following accessions numbers: GQ374243 (CsPDR8) and GQ374244 (CsPDR12). Additional accession numbers are provided in Table 3.

Statistical analyses

The qPCR data were analyzed by the $\Delta \Delta \mathrm{CT}$ method using the LightCycler ${ }^{\circledR}$ Software 4.1 (Roche). Student's $t$ test and ANOVA (Excel) were used to confirm the statistical significance of difference in $C s P D R s$ expression between control and hormone-treated plants.

\section{Results}

Identification of cucumber genes homologous to Arabidopsis thaliana PDR8 and PDR12

The full sequences of two CsPDRs were cloned using a RACE-PCR approach and designated CsPDR8 and CsPDR12, according to their homology with AtPDR genes. The entire cDNAs of $C s P D R 8$ and $C s P D R 12$ contain an uninterrupted open reading frame of 4,428 bp and 4,356 bp long, respectively; hence, the putative proteins encoded by the two cucumber genes contain 1,475 and 1,451 amino acids, respectively. Both proteins have all domains and motifs characteristic of plant pleiotropic drug resistance type $\mathrm{ABC}$ transporters (ABCG), for example, two hydrophilic nucleotide binding folds (NBFs) (ABC_PDR_domain1 and ABC_PDR_domain2) and two hydrophobic transmembrane domains (TMD), the first with six, the second with seven transmembrane spanning regions, according to TMHMM 2.0 Server (Fig. 1). The cytosolic loops containing NBFs precede the transmembrane domains, giving a typical reverse configuration, [NBF$\mathrm{TMD}_{2}$, specific to all PDR proteins (Fig. 1). Within the two NBF domains, Walker A, Walker B and ABC signature motifs have been identified, while the PDR-associated domain has been recognized within the sixth span of transmembrane domain 1 (Figs. 1, 2). Both CsPDR8 and CsPDR12 exhibit a high degree of homology at the nucleic acid (62\%) and amino acid (58\%) level. Nevertheless, CsPDR8 and CsPDR12 are more similar to their close homologs of Arabidopsis thaliana, AtPDR8/AtABCG36 and AtPDR12/AtABCG40, with identity of $69 \%$ at the nucleic acid level (CsPDR8 with AtPDR8/AtABCG36 and CsPDR12 with AtPDR12/AtABCG40), and $72 \%$ (CsPDR8 with AtPDR8/AtABCG36) and $70 \%$ (CsPDR12 with AtPDR12/AtABCG40) at the amino acid level.

The PDR protein family of cucumber

The release of the cucumber genome sequence (Huang et al. 2009) allowed for a first inventory of all cucumber genes encoding for PDR proteins. Through the screening of the whole cucumber genome shotgun reads submitted to GenBank, we have identified 16 genes that were homologous to 15 AtPDRs available in the Aramemnon database (Table 3). To date, only two cDNAs of cucumber PDR genes remain cloned to their full length: CsPDR8 and CsPDR12, which are described here. Research on the cucumber genome revealed that CsPDR8 and CsPDR12 
Table 3 Pleiotropic drug resistance (PDR) transporters genes identified in the whole cucumber genome shotgun reads database (GenBank)

\begin{tabular}{|c|c|c|c|c|c|c|c|c|}
\hline $\begin{array}{l}\text { Arabidopsis gene } \\
\text { abbreviation }\end{array}$ & $\begin{array}{l}\text { Cucumis source gene }{ }^{a} \\
\text { (gene abbreviation) }\end{array}$ & $\begin{array}{l}\text { Ortholog } \\
\text { locus }\end{array}$ & $\begin{array}{l}\text { Position of } \\
\text { predicted } \\
C s P D R \text { genes }\end{array}$ & $\begin{array}{l}\text { Length of } \\
\text { gene (bp) }\end{array}$ & $\begin{array}{l}\text { Length of } \\
\text { protein } \\
\text { (aa) }\end{array}$ & $\begin{array}{l}\text { Number of } \\
\text { predicted } \\
\text { exons }\end{array}$ & $\begin{array}{l}\text { Number of } \\
\text { predicted } \\
\text { introns }\end{array}$ & $\begin{array}{l}\text { Identitity } \\
\%\end{array}$ \\
\hline $\begin{array}{l}\text { AtABCG29 } \\
(A t P D R 1)\end{array}$ & $\begin{array}{l}\text { ACHR01006946 (+) } \\
(C s P D R 1)\end{array}$ & At3g16340 & $24870-33617$ & 4,302 & 1,433 & 20 & 19 & 67 \\
\hline $\begin{array}{l}\text { AtABCG30 } \\
(A t P D R 2)\end{array}$ & $\begin{array}{l}\text { ACHR01001960 (+) } \\
(C s P D R 2)\end{array}$ & At4g15230 & 11014-20385 & 4,521 & 1,506 & 25 & 24 & 48 \\
\hline $\begin{array}{l}\text { AtABCG31 } \\
(A t P D R 3)\end{array}$ & $\begin{array}{l}\text { ACHR01006356/ } \\
\text { ACHR01006357 (+) } \\
(C s P D R 3)\end{array}$ & At2G29940 & $14846-26115$ & 3,903 & 1,300 & 23 & 22 & 72 \\
\hline $\begin{array}{l}\text { AtABCG32 } \\
(A t P D R 4)\end{array}$ & $\begin{array}{l}\text { ACHR01002610 (-) } \\
(C s P D R 4)\end{array}$ & At2g26910 & 70024-78384 & 4,230 & 1,409 & 24 & 23 & 77 \\
\hline $\begin{array}{l}\text { AtABCG33 } \\
\text { (AtPDR5) }\end{array}$ & $\begin{array}{l}\text { ACHR01000871/ } \\
\text { ACHR01000872 (+) } \\
(\text { CsPDR5) }\end{array}$ & At2g37280 & 2921-13445 & 4,287 & 1,428 & 23 & 22 & 62 \\
\hline \multirow[t]{2}{*}{$\begin{array}{l}\text { AtABCG34 } \\
(\text { AtPDR6) }\end{array}$} & $\begin{array}{l}\text { ACHR01006492 (-) } \\
(C s P D R 6)\end{array}$ & At2g36380 & 7299-15082 & 4,260 & 1,419 & 20 & 19 & 70 \\
\hline & $\begin{array}{l}\text { ACHR01001600 (-) } \\
(C s P D R 16)\end{array}$ & At2g36380 & 7299-15082 & 4,260 & 1,419 & 20 & 19 & 66 \\
\hline $\begin{array}{l}\text { AtABCG35 } \\
(\text { AtPDR7) }\end{array}$ & $\begin{array}{l}\text { ACHR01001369 (-) } \\
(C s P D R 7)\end{array}$ & At1g15210 & 19090-25244 & 4,131 & 1,376 & 21 & 20 & 50 \\
\hline $\begin{array}{l}\text { AtABCG36 } \\
\text { (AtPDR8) }\end{array}$ & $\begin{array}{l}\text { ACHR01014054 (-) } \\
(C s P D R 8)\end{array}$ & At1g59870 & 1819-8895 & 4,428 & 1,475 & 22 & 21 & 72 \\
\hline $\begin{array}{l}\text { AtABCG37 } \\
(A t P D R 9)\end{array}$ & $\begin{array}{l}\text { ACHR01000873/ } \\
\text { ACHR01000874 (+) } \\
(C s P D R 9)\end{array}$ & At3g53480 & $325-5088$ & 3,795 & 1,264 & 21 & 20 & 61 \\
\hline $\begin{array}{l}\text { AtABCG38 } \\
(\text { AtPDR10) }\end{array}$ & $\begin{array}{l}\text { ACHR01012132 (+) } \\
(C s P D R 10)\end{array}$ & At3g30842 & 2736-10659 & 4,356 & 1,451 & 24 & 23 & 59 \\
\hline $\begin{array}{l}\text { AtABCG39 } \\
(\text { AtPDR11) }\end{array}$ & $\begin{array}{l}\text { ACHR01008429 (-) } \\
(C s P D R 11)\end{array}$ & At1g66950 & $46106-54045$ & 4,332 & 1,443 & 19 & 18 & 68 \\
\hline $\begin{array}{l}\text { AtABCG40 } \\
(A t P D R 12)\end{array}$ & $\begin{array}{l}\text { ACHR01010243 (+) } \\
(C s P D R 12)\end{array}$ & At1g15520 & 6599-14203 & 4,356 & 1,451 & 23 & 22 & 70 \\
\hline $\begin{array}{l}\text { AtABCG41 } \\
(\text { AtPDR13) }\end{array}$ & $\begin{array}{l}\text { ACHR01004252 (+) } \\
(C s P D R 13)\end{array}$ & At4g15215 & $907-24813$ & 3,792 & 1,263 & 21 & 20 & 60 \\
\hline $\begin{array}{l}\text { AtABCG42 } \\
(\text { AtPDR14) }\end{array}$ & $\begin{array}{l}\text { ACHR01010133 (+) } \\
(C s P D R 14)\end{array}$ & At4g15233 & $5472-15168$ & 4,170 & 1,389 & 26 & 25 & 48 \\
\hline $\begin{array}{l}\text { AtABCG43 } \\
(A t P D R 15)\end{array}$ & $\begin{array}{l}\text { ACHR01000615 (-) } \\
(C s P D R 15)\end{array}$ & At4g15236 & $9751-16365$ & 4,272 & 1,423 & 24 & 23 & 59 \\
\hline
\end{tabular}

${ }^{a}$ Accession number of contigs containing CsPDRs and orientation of strand encoding PDR proteins (+ for direct or - for complementary)

b The identities of cucumber and Arabidopsis orthologs were calculated using ClustalW

sequences can be found in the contigs ACHRO10014054 and ACHRO10010243, respectively, and allowed for a more profound analysis of the DNA sequence of both genes. It was found that CsPDR8 has 22 exons (each 54-369 bp long) and 21 introns, whereas the slightly longer CsPDR12 has 23 exons (each 54-393 bp long) and 22 introns (Table 3, Fig. 3A). The $5^{\prime}$ and $3^{\prime}$ untranslated regions in CsPDR8 have 249 and $302 \mathrm{bp}$, respectively, whereas $C s P D R 125^{\prime} \mathrm{UTR}$ and $3^{\prime} \mathrm{UTR}$ regions are 672 and 142 bp long, respectively. According to ProtComp v. 9.0 prediction, the proteins encoded by $C s P D R 8$ and $C s P D R 12$ localize to the plasma membrane (Fig. 3b). Both CsPDR8 and CsPDR12 as well as the other predicted CsPDR protein sequences were used to construct the updated phylogenetic tree of plant PDR proteins using the neighbor-joining method (Fig. 4). The arrangement of sequences in the phylogenetic tree suggests four main clusters. Cluster I includes the majority of Arabidopsis PDRs (PDR2, PDR5, PDR9-10, PDR13-15), four cucumber PDRs (PDR5, PDR9-10 and PDR13), 5 rice PDRs (PDR1-2, PDR14, 
Fig. 1 Topology prediction of CsPDR8 and CsPDR12 according to TMHMM 2.0 Server (Sonnhammer et al. 1998)
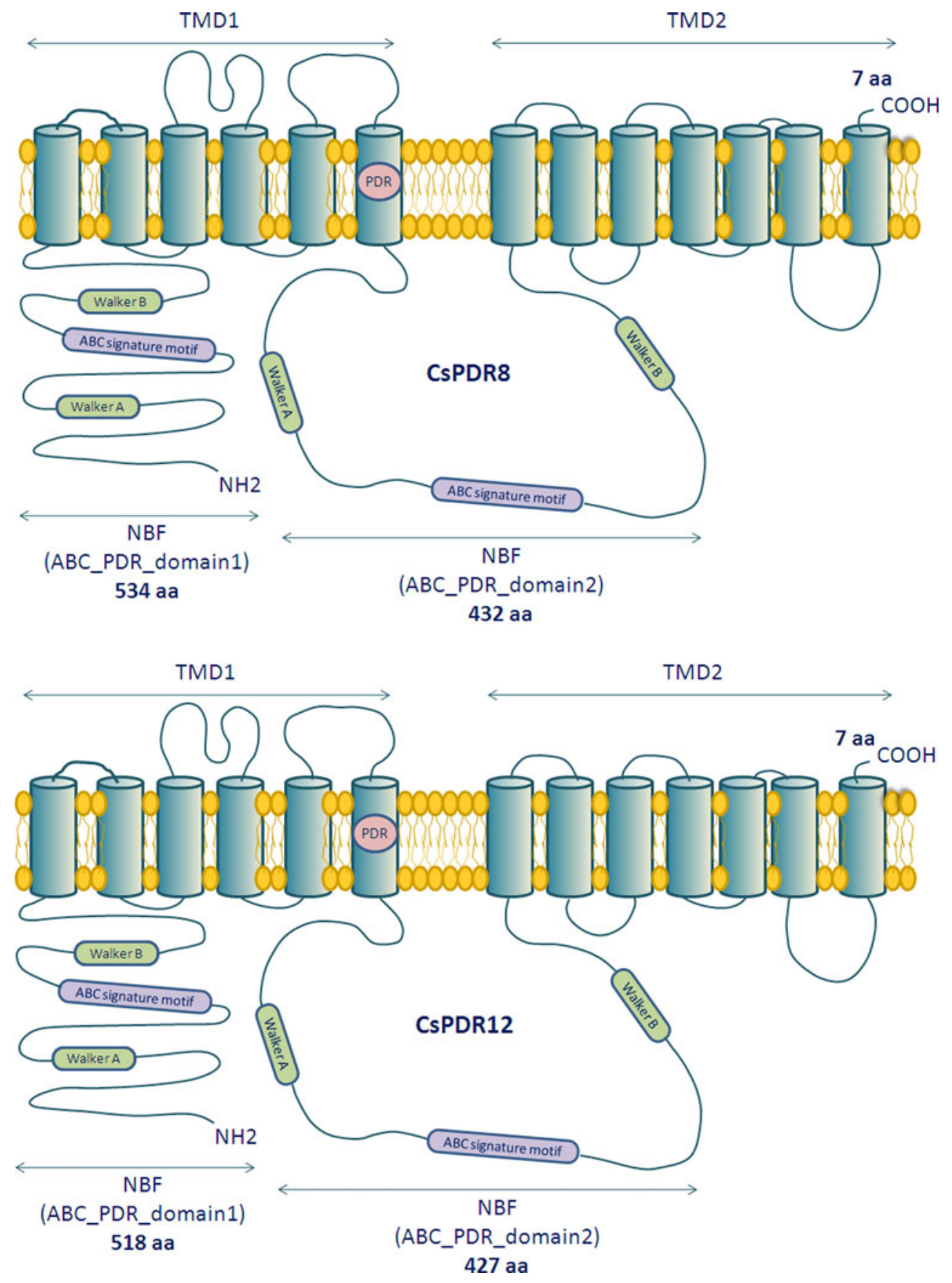

PDR22-23) and PDR3 of Nicotiana tabacum (Fig. 4). Another five cucumber PDRs (PDR4, PDR6, PDR11 and PDR15-16) and three AtPDRs (PDR4, PDR6 and PDR11) belong to cluster II together with three PDRs from rice (OsPDR3, OsPDR5-6), two from Nicotiana plumbaginifolia (Np40786 and NpPDR2), one from Vitis vinifera and one from Triticum aestivum (Fig. 4). Cluster III contains four Arabidopsis PDRs (PDR1, PDR3 and PDR7-8) together with 4 homologous cucumber PDRs (PDR1, PDR3 and PDR7-8), six rice PDRs (PDR9-13 and PDR15), two PDRs of Populus and two PDRs of Vitis (Fig. 4). The remaining three cucumber PDR proteins (PDR2, PDR12 and PDR14) belong to cluster IV, which contains Arabidopsis PDR12, the majority (8) of rice PDRs (PDR4, PDR7-8, PDR16-17 and PDR19-21), two Populus PDRs, three Nicotiana PDRs and one PDR from Glycine max and Spirodela polyrhiza (Fig. 4). Since CsPDR8 and CsPDR12 belong to two different clusters, it may be suggested that both proteins are involved in different physiological reactions of cucumber cells. Indeed, further analyses of organ expression of the genes encoding for CsPDR8 and CsPDR12, as well as their transcriptional profile under different plant growth 


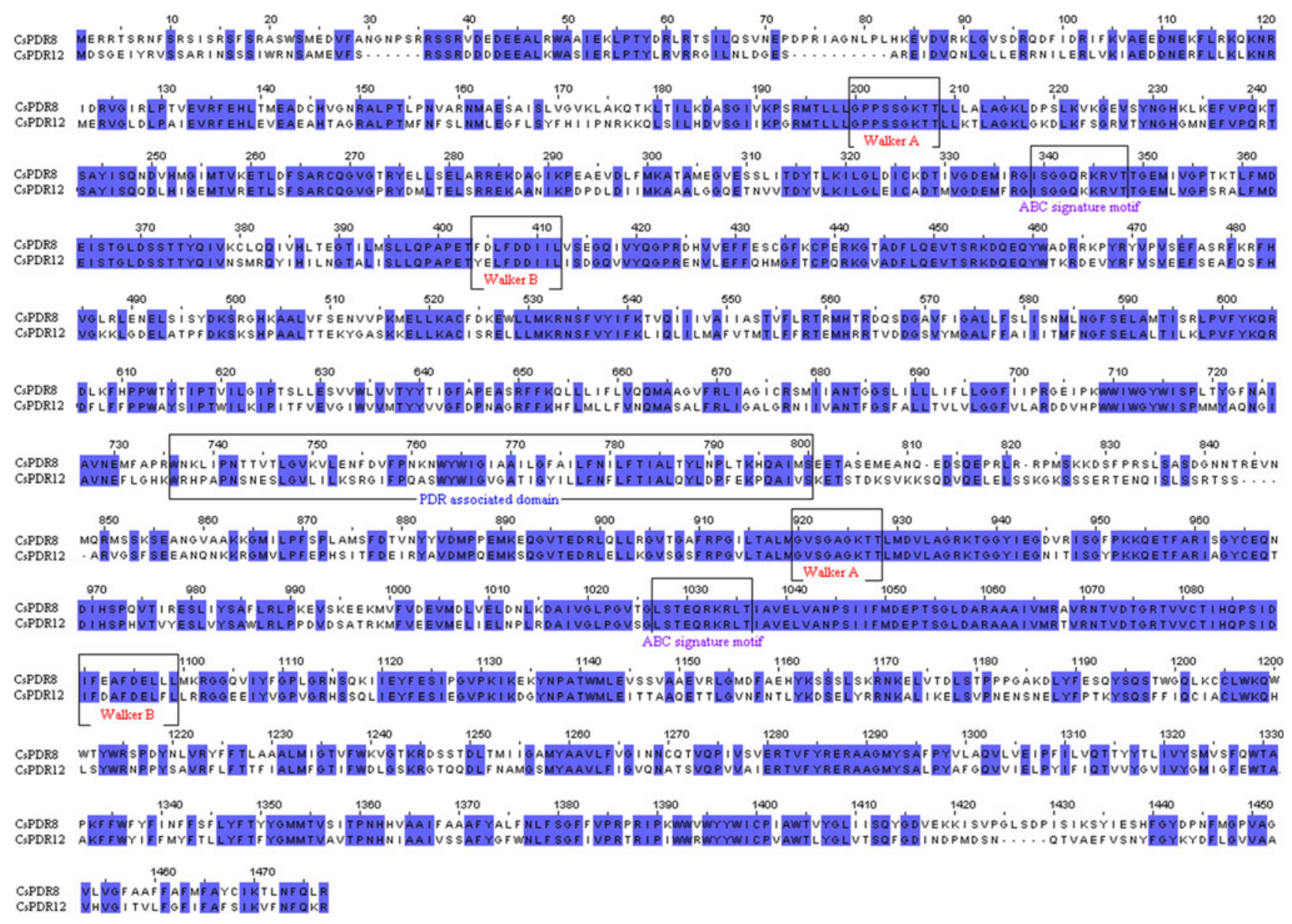

Fig. 2 The alignment of CsPDR8 and CsPDR12 protein sequences with ClustalW (Higgins et al. 1996). ABC signature, Walker A and Walker B motifs as well as PDR-associated domain are presented in boxes

regulators, revealed differences in the function/regulation of both proteins within plant cells.

Transcriptional analysis of CsPDR8 and CsPDR 12 in various cucumber organs at two different developmental stages

To address the questions whether CsPDR8 and CsPDR12 function in the same or different tissue types or whether they are associated with a broad range of tissues or are specifically expressed in a particular tissue type, we assessed their organ expression patterns using both vegetative organs and inflorescence (Fig. 5). According to RTPCR analysis, the highest level of CsPDR8 expression was observed in roots of 1-week-old seedlings (Fig. 5). At this stage of development, a small amount of CsPDR8 mRNA was also detected in cotyledons and petioles of the first leaves (Fig. 5). Similar to CsPDR8, the expression of CsPDR 12 in young seedlings was also enhanced in roots, and in addition, a low level of transcript was detectable in petioles but not in cotyledons (Fig. 5). In 8-week-old plants, the level of CSPDR8 mRNA was slightly detectable only in roots, whereas CsPDR12 mRNA was the most abundant in roots and significantly lower but clearly detectable in male perianth, female perianth and pistils (Fig. 5). Roots of 1-week-old seedlings were chosen for further analysis of the expression of CsPDR8 and CsPDR12 under plant growth regulators including mainly phytohormones.

The transcriptional profiling of $C s P D R 8$ and $C s P D R 12$ in roots in response to phytohormones and plant growth regulators

Using real-time PCR, we performed transcriptional profiling of CsPDR8 and CsPDR12 in roots of 1-week-old cucumbers in response to plant growth regulators. The regulators included hormones involved in the plant response to biotic (SA, JA) and abiotic (ABA) stress as well as molecules crucial for plant growth and development (IAA, kinetin, GA3), phytotoxic herbicide (2,4-D) and ethylene precursor (ACC). Jasmonic acid and salicylic 

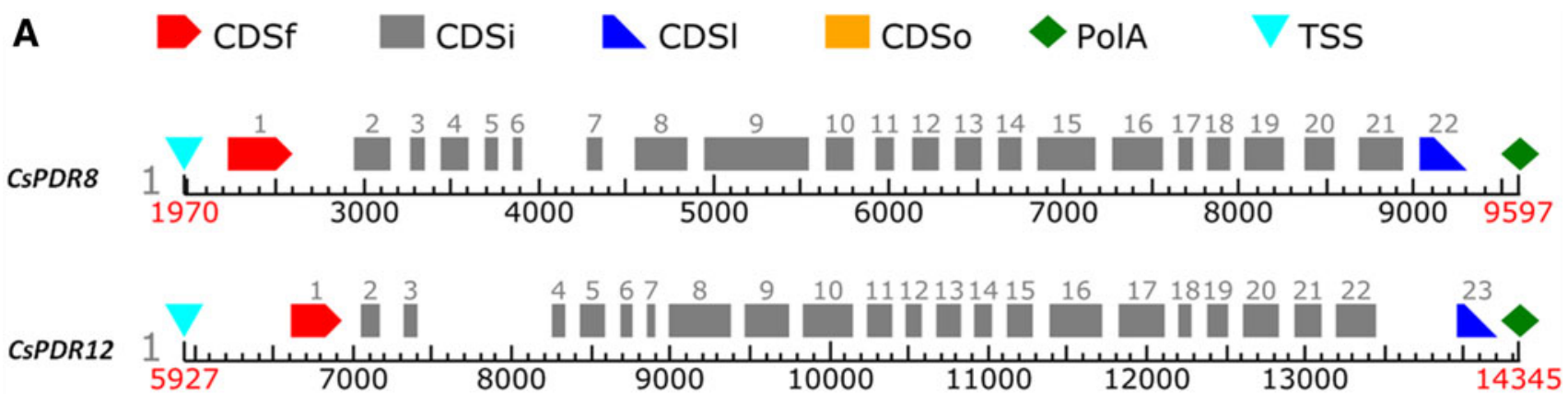

B

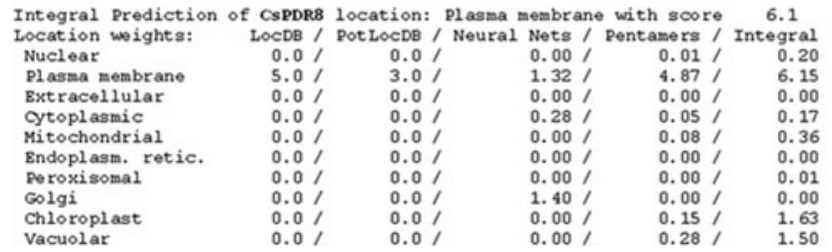

Fig. 3 The genomic organization (a) of CsPDR8 and CsPDR12 and subcellular localization (b) of the proteins encoded by two cucumber genes. The cDNAs were previously sequenced and the whole gene structures were predicted using FGENESH software (softberry.com). Plasma membrane localization of two CsPDRs was predicted using

acid proved to be the main stimulators of CSPDR 8 and CsPDR 12 expression, respectively. 5-20 $\mu \mathrm{M} \mathrm{JA}$ increased the level of CsPDR8 and CSPDR12 mRNAs up to 4-fold and over 5-fold, respectively (Fig. 6a, b). The effect of SA on both genes was clearly dependent on phytohormone concentration. CSPDR8 mRNA level was markedly increased only at the highest $(10-20 \mu \mathrm{M})$ SA concentrations, whereas CsPDR12 expression increased significantly in the SA range tested $(5-20 \mu \mathrm{M})$. Nevertheless, CsPDR 8 expression was enhanced over 2-fold by salicylic acid, whereas CSPDR12 mRNA increased up to 14-fold in response to the hormone (Fig. 6a, b). The expression of CsPDR 8 was more enhanced by the $100-200 \mu \mathrm{M}$ ethylene precursor ACC, which did not affect CsPDR12 transcript (Fig. 6a, b). ACC stimulated CsPDR8 expression over 3 -fold (Fig. 6a). In contrast, the treatment of plants with ABA, another stress-related hormone, resulted in a significant decrease in CsPDR 8 mRNA (up to $50 \%$ ) causing a concentration-dependent increase (up to twofold) in CsPDR12 transcription (Fig. 6a, b). Besides hormones associated with the plant response to stress, the synthetic auxin 2,4-D markedly (6-fold) upregulated CsPDR12 expression when used in the highest $(5 \mu \mathrm{M})$ concentration (Fig. 7b). However, the auxinic compound had no influence on $C s P D R 8$ mRNA level. Of all other hormones used, only 5-50 $\mu \mathrm{M}$ concentrations of kinetin caused a concentration-dependent, up to 4-fold, increase in CsPDR 12 transcript, but similar to 2,4-D had no effect on CsPDR8 expression (Fig. 7a, b). Only auxin and GA3 did not

\begin{tabular}{|c|c|c|c|c|c|}
\hline Location weights: & LOCDB / & Pot LocDB / Neural & Nets / & Pentamers / & Integral \\
\hline Nuclear & 0.01 & $0.0 \%$ & $0.07 /$ & $0.02 /$ & 0.00 \\
\hline Plasma membrane & $5.0 \%$ & $3.0 \%$ & $2.37 \%$ & $4.87 \%$ & 9.66 \\
\hline Extracellular & $0.0 \%$ & 0.01 & $0.00 \%$ & $0.00 \%$ & 0.00 \\
\hline Cytoplasmic & $0.0 /$ & $0.0 /$ & $0.00 /$ & $0.06 /$ & 0.01 \\
\hline Mitochondrial & $0.0 /$ & $0.0 /$ & $0.00 /$ & $0.06 /$ & 0.05 \\
\hline Endoplasm. retic. & 0.01 & 0.01 & $0.00 \%$ & $0.00 \%$ & 0.00 \\
\hline Poroxigomal & $0.0 \%$ & 0.01 & $0.00 \%$ & $0.00 \%$ & 0.00 \\
\hline Golgi & $0.0 \%$ & $0.0 \%$ & $0.15 \%$ & $0.00 \%$ & 0.00 \\
\hline Chloroplast & 0.01 & 0.01 & $0.06 \%$ & $0.08 /$ & 0.00 \\
\hline Vacuolar & $0.0 \%$ & 0.01 & $0.36 /$ & 0.28 , & 0.28 \\
\hline
\end{tabular}

ProtComp v. 9.0 (software (sofberry.com). CDSf first coding segment (starting with start codon), CDSi internal exon, CDSl last coding segment (ending with stop codon), TSS position of transcription start (TATA-box position)

significantly influence the transcription of both cucumber PDRs (Fig. 7a, b).

\section{Discussion}

In this work, we present the first identification of $P D R$ genes as well as predicted PDR proteins in cucumber. Two of the PDRs had been previously sequenced and submitted to GenBank as homologs of AtPDR8/AtABCG36 and AtPDR 12/AtABCG40, according to their structural similarity to Arabidopsis PDRs. In addition to that, cucumber genome-wide screening revealed the presence of the remaining 14 homologs of Arabidopsis PDRs in cucumber (Table 3). The predicted proteins of the CsPDR family were subjected to phylogenetic analysis revealing that CsPDR8 and CsPDR12 belong to two different clusters, III and IV, respectively (Fig. 4). CsPDR8 clusters with its closest Arabidopsis homolog, AtPDR8/AtABCG36, which has been shown to contribute to the response to pathogen infection, detoxification of heavy metals $(\mathrm{Cd}$ and $\mathrm{Pb})$ in plant cells and transmembrane transport of herbicides $(2,4-$ D) and IBA (Kobae et al. 2006; Kim et al. 2007; Strader and Bartel 2009). The transcription of CsPDR8 was markedly upregulated by jasmonic acid, ethylene precursor and, to a lesser extent, by salicylic acid (Fig. 6a). In contrast, ABA significantly reduced the rate of gene expression (Fig. 6a). Since other plant growth regulators did not influence $C S P D R 8$ transcript, it may be suggested that the 


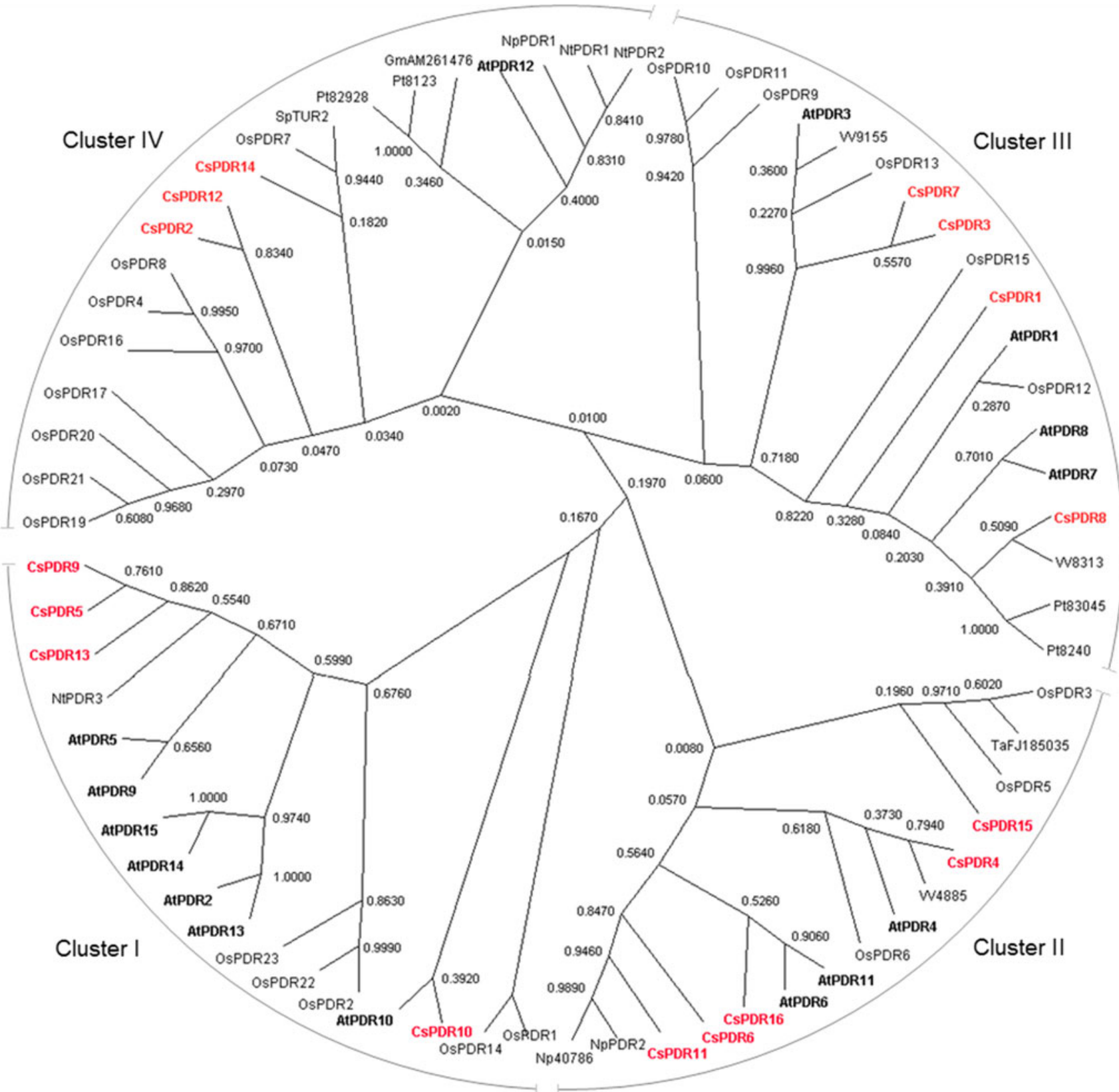

Fig. 4 Phylogenetic relationships of the 16 predicted PDR-like transporters identified in cucumber and PDR-like representatives from other plants. The unrooted tree was constructed by the MEGA5.1 software (Tamura et al. 2011) using the neighbor-joining method with 1.000 bootstrap replicate trees. The accession numbers are as follows: Arabidopsis thaliana, AtPDR1 (DAA00870), AtPDR2 (DAA00869), AtPDR3 (DAA00871), AtPDR4 (DAA00872), AtPDR5 (DAA00873), AtPDR6 (DAA00874), AtPDR7 (DAA00875), AtPDR8 (DAA00876), AtPDR9 (DAA00877), AtPDR10 (DAA00878), AtPDR11 (DAA00879), AtPDR12 (DAA00880), AtPDR13 (DAA00881), AtPDR14(DAA00882), AtPDR15 (DAA00883); Oryza sativa, OsPDR1 (CAD59576 or Q8GU82), OsPDR2 (CAD59575 or Q8GU83), OsPDR3 (CAD59574 or Q8GU84), OsPDR4 (DAA00887), OsPDR5 (Q8GU86), OsPDR6 (Q8GU87), OsPDR7 (Q8U88 or CAD59570), OsPDR8 (Q8GU89 or CAD59569),
OsPDR9 (AAQ02685, Q8GU90 or CAD59568), OsPDR10 (Q7PC80 or DAA00884), OsPDR11 (Q8GU92 or CAD59566 or DAA00885), OsPDR12 (Q5Z9S8 or CAD59565), OsPDR13 (Q8S628 or CAD59564), OsPDR14 (AJ535214), OsPDR15 (Q7FMW4 or CAD59563), OsPDR16 (AAQ01165), OsPDR17 (Os08g29570), OsPDR19 (EAZ44308), OsPDR20 (EU682752 or EAZ44307), OsPDR21 (Os09g16290), OsPDR22 (Os12g13720), OsPDR23 (Os12g32820); Populus trichocarpa, Pt83045 (EEE83045), Pt8240 (EEE8240), Pt82928 (EEE82928), Pt8123 (XP_002298123); Nicotiana plumbaginifolia, NpPDR1 (CAC40990), NpPDR2 (AJ831424), Np40786 (CAH40786); Nicotiana tabacum, NtPDR1 (BAB92011), NtPDR2 (BAD07484), NtPDR3 (CAH39853); Triticum aestivum, (TaFJ185035); Glycine max, GmPDR12 (AM261476); Spirodela polyrhiza, SpTUR2 (CAA94437); Vitis vinifera, VV9155 (XP_002279155, VV4885(XP_002284885), VV8313 (XP_002278313) 

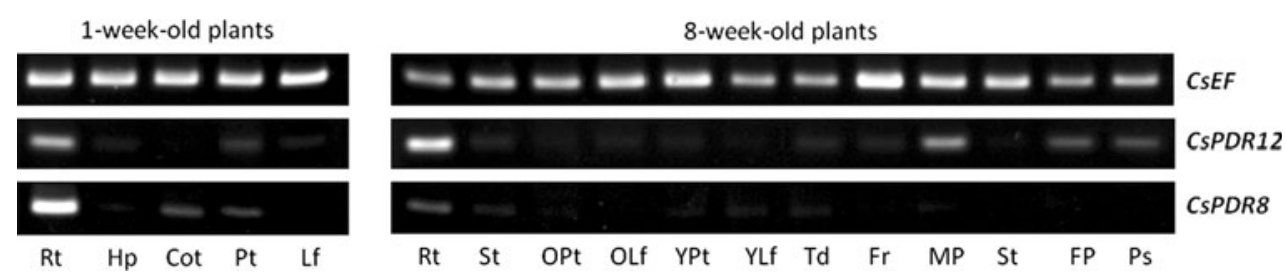

Fig. 5 Semiquantitative RT-PCR analysis of the organ expression pattern of CSPDR8 and CSPDR12 in 1-week-old and 8-week-old cucumber plants. Gene encoding for elongation factor $(\mathrm{EF} \alpha)$ was used as an internal control. Rt roots, $\mathrm{Hp}$ hypocotyls, Cot cotyledons, Pt

pistil, $L f$ leaf, $S$ stem, $O P t$ old pistil, $O L f$ old leaf, $Y P t$ young pistil, $Y L f$ young leaf, $T d$ tendril, $F r$ fruit, $M P$ male perianth, $S t$ stamen, $F P$ female perianth, $P s$ pistil

Fig. 6 Quantitative real-time PCR analysis of $C S P D R 8$ (a) and CsPDR12 (b) expression in roots of 1-week-old cucumbers treated with $\mathrm{ABA}$ $(2,5,10,50 \mu \mathrm{M}), \mathrm{SA}(5,10$, $20 \mu \mathrm{M})$, ACC $(100,150$, $200 \mu \mathrm{M}$ and JA $(5,10,20 \mu \mathrm{M})$ for $4 \mathrm{~h}$. Control plants were treated with the equivalent amount of methanol (the solvent of JA and $\mathrm{ABA}$ ) or water. The expression data were analyzed using reference gene encoding for elongation factor $(\mathrm{EF} \alpha)$ as an internal control. Asterisks indicate significant differences between control and hormonetreated plants $(t$ test; $* P<0.05)$
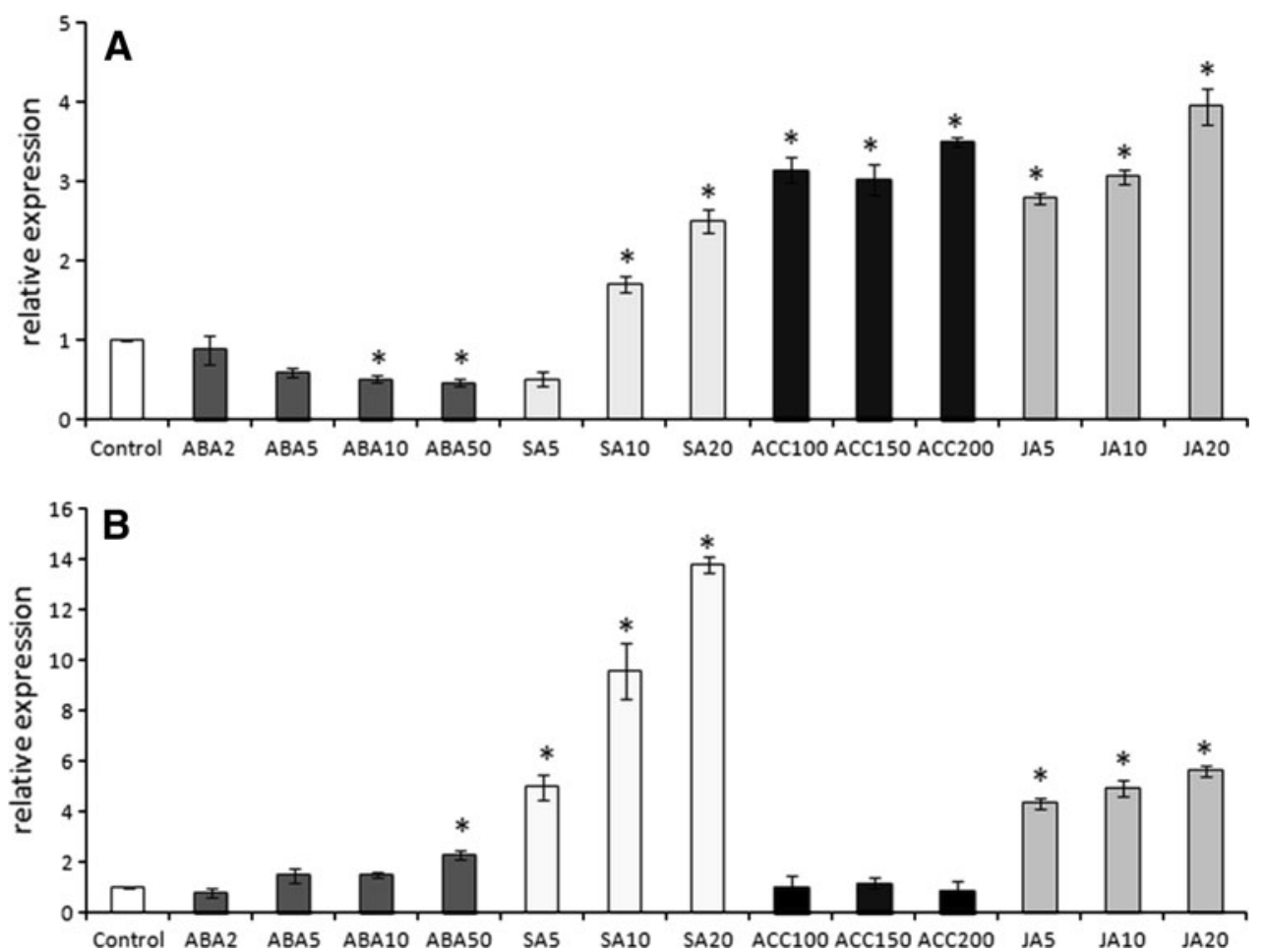

function of CsPDR8 may be specifically related to the plant responses to biotic or abiotic stress which are mediated by salicylic acid, jasmonic acid, ethylene and/or ABA (Fig. 6a). JA and SA are known to control the local apoptotic hypersensitivity response (HR) and induce systemic acquired resistance (SAR) during pathogen invasion. JA is important in response to wounding and for development processes including growth inhibition, senescence, flower development and leaf abscission (Delker 2006). SA also contributes to the responses to some abiotic stresses such as low and high temperature, UV-B irradiation, ozone and heavy metals (Janda et al. 2007). Ethylene is another plant hormone associated with senescence and response to stress. Plants produce higher levels of ethylene under biotic or abiotic stress, such as pathogen attack, salt, wounding, drought, heat, flooding, low phosphorus (Borch et al. 1999) and low iron (Romera et al. 1999). It has been previously suggested that the compounds transported by PDRs
(AtPDR6 and AtPDR11) include antifungal and antimicrobial chemicals that are required for plant protection against pathogen attack (Jasinski et al. 2001; Stukkens et al. 2005; Kobae et al. 2006; Stein et al. 2006; Badri et al. 2007). Like AtPDR6/AtABCG34 and AtPDR11/AtABCG39, cucumber $P D R 8$ is constitutively expressed in root tissue (Fig. 5), which may suggest the possible involvement of the protein in the secretion of exudates in response to external stimuli. CsPDR8 clusters together with OsPDR9 (Fig. 4), which has been shown to be upregulated by phytohormones IAA, cytokinin and JA at the level of mRNA transcription (Moons 2003; Table 1). The different responses of rice and cucumber $P D R$ to IAA and cytokinin suggest that structural homologs of PDRs in monocot and dicot plants are subjected to different modes of regulation by plant hormones.

Similar to $C s P D R 8$, the expression of $C s P D R 12$ was also stimulated by salicylic acid and jasmonic acid. 
Fig. 7 Quantitative real-time PCR analysis of $C s P D R 8$ (a) and CsPDR12 (b) expression in roots of 1-week-old cucumbers treated with IAA $(5,10,30,50 \mu \mathrm{M}), 2,4-\mathrm{D}(0,5$, 2, $5 \mu \mathrm{M}$ ), kinetin (KIN, 5, 20, $50 \mu \mathrm{M})$ and GA3 (GA, 5, 20, $50 \mu \mathrm{M})$ for $4 \mathrm{~h}$. Control plants were treated with the equivalent amount of methanol (the solvent of IAA and 2,4-D) or water. The expression data were analyzed using reference gene encoding for elongation factor (CsEF) as an internal control. Data are the mean $\pm \mathrm{SD}$ of at least three independent RNA samples. The results were analyzed by the $\Delta \Delta C T$ method using the LightCycler ${ }^{\circledR}$ Software 4.1 (Roche). Asterisks indicate significant differences between control and hormone-treated plants $(t$ test; $* P<0.05)$
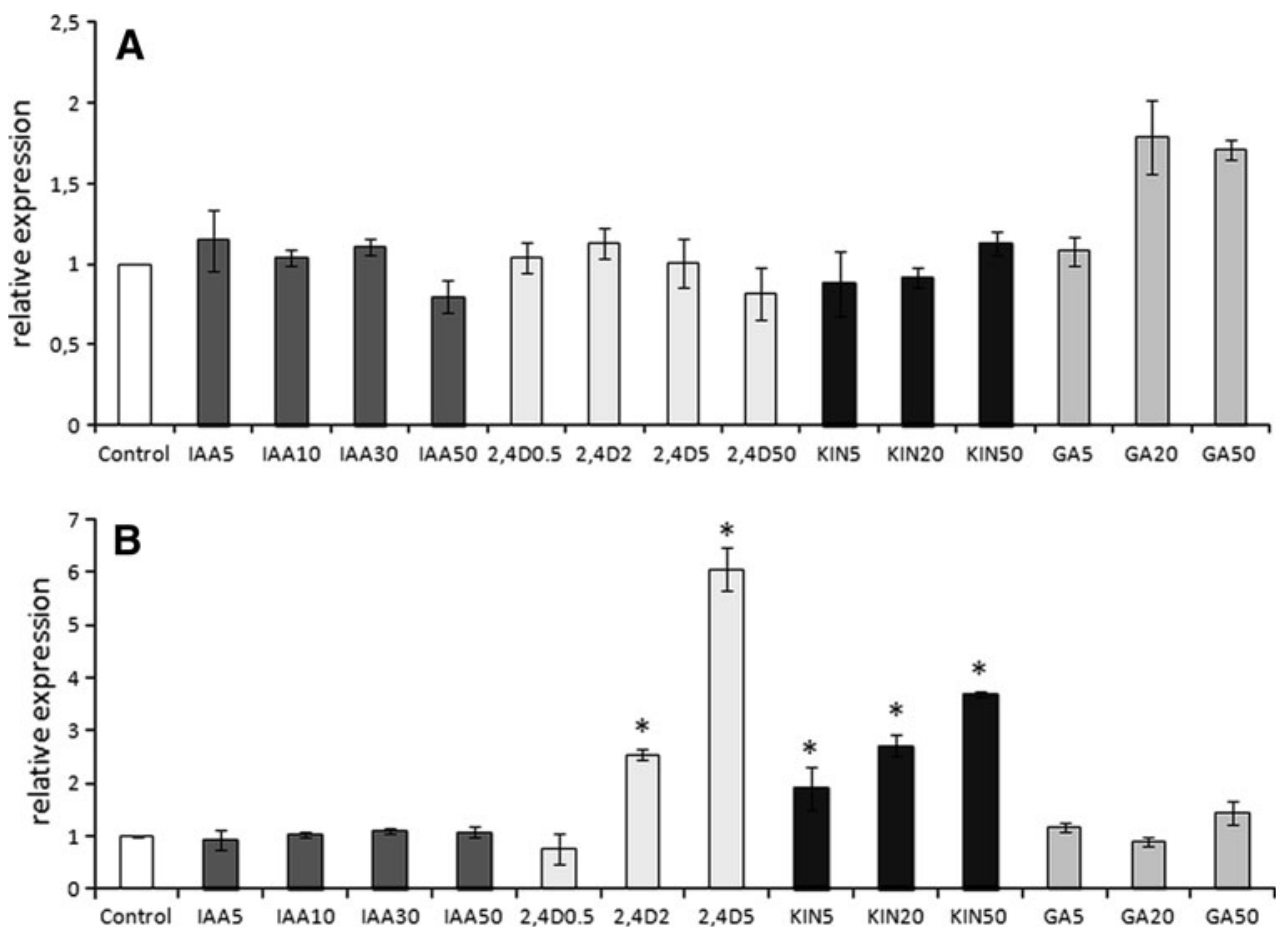

However, SA caused a considerably high increase in the gene transcription when compared with the other growth regulators (Fig. 6b). GmPDR12 and OsPDR20, other proteins that cluster together with CsPDR12 and AtPDR12/ AtABCG40, were also markedly induced by both JA and SA or SA and pathogen stress, respectively (Moons 2003; Eichhorn et al. 2006), confirming that PDR12-like proteins fulfill similar functions in different plants. NpPDR1 and NtPDR1, clustering with CsPDR12, have been implicated in pathogen defense (Table 1), possibly through the efflux of antimicrobial and antifungal metabolites out of plant cells (Jasinski et al. 2001; Sasabe et al. 2002; Stukkens et al. 2005). Hence, PDR12-like proteins seem to be key players in the pathogen-induced response. Furthermore, ABA also upregulated $C s P D R 12$ expression. ABA is known to participate in many physiological processes in plants, including seed germination, stomata closure, seedling growth and lateral root development, resistance to drought and other biotic and abiotic stresses, including salinity and pathogen infection. It has been recently demonstrated that the CsPDR12 homolog AtPDR12/AtABCG40 mediates the closure of stomata in response to water deficit through the active ABA transport into mesophyll cells (Kang et al. 2010). In addition, Spirodela PDR clustering together with AtPDR12/AtABCG40 and CsPDR12 (Fig. 4) was also significantly induced by ABA (Smart and Fleming 1996). The SpTUR2 transcript was also elevated upon salinity and low temperature (Smart and Fleming 1996), suggesting the involvement of Spirodela PDR in the ABA-mediated response to these abiotic stresses. The response of $C S P D R 12$ to hormones mediating the stress response suggests that cucumber protein is functionally similar to its Arabidopsis and Spirodela homologs.

Although CsPDR12 seems to be involved in the ABAmediated response to stress, contrary to CsPDR8, it may not contribute to the ethylene-mediated reaction to environmental stimuli, since ACC did not influence the level of CsPDR12 mRNA (Fig. 6a, b). Unlike CsPDR8, CsPDR12 mRNA was markedly elevated by auxinic herbicide 2,4-D (Fig. 7b). This may suggest that besides ABA, the protein may be capable of transporting auxinic compounds. Indeed, it has been recently demonstrated that PDR proteins may be involved in the transmembrane movement of different auxinic compounds. The direct efflux of IBA or IBA and 2,4-D has been demonstrated using Schizosaccharomyces pombe cells and mammalian cells, respectively, expressing AtPDR9 (Růžička et al. 2010).

The strong stimulation of $C s P D R 12$ by kinetin was in line with the frequent induction of rice $P D R s$ in roots by another cytokinin, 6-benzylaminopurine, and confirmed the need for some of the PDR proteins in root meristematic tissues (Moons 2003, 2008). OsPDR8 and OsPDR17, clustering together with CsPDR12 and AtPDR12/AtABCG40 (Fig. 4), are two of the six OsPDRs significantly stimulated by cytokinin in roots (Table 1). However, all the implications regarding the function of cucumber PDRs require confirmation in further research.

Summing up, we present the first depiction of cucumber PDRs, revealing the presence of at least 16 genes encoding 
PDR proteins in Cucumis sativus. In addition, we provide evidence for the phytohormone-mediated regulation of at least two CsPDRs, CsPDR8 and CsPDR12. The organ expression pattern of $C s P D R 8$ and $C s P D R 12$ suggests that the proteins are specific to roots and, in the case of PDR12, for flowers. The results confirm the previous data demonstrating the involvement of phytohormones (ABA, ethylene, jasmonates, salicylic acid, cytokinins) and plant growth regulators $(2,4-\mathrm{D}$, auxinic compounds) in the regulation of PDR protein synthesis and/or function in plants. Nevertheless, the precise mechanism of interaction between PDRs and phytohormones or their precursors still remains to be clarified. Interestingly, the genes encoding the two cucumber proteins respond to phytohormones in a distinct way, suggesting dissimilar functions of CsPDR8 and CsPDR12 in the response of plant cells to stimuli involving hormone-mediated signaling pathways.

Acknowledgments This work was financially supported by Wroclaw University (grant 2245/W/IBR/09) and the Polish Committee of Science (grant 2P04C 123 29).

Open Access This article is distributed under the terms of the Creative Commons Attribution License which permits any use, distribution, and reproduction in any medium, provided the original author(s) and the source are credited.

\section{References}

Badri DV, Loyola-Vargas VM, Broeckling CD, De-la-Pena C, Jasinski M, Santelia D, Martinoia E, Sumner LW, Banta LM, Stermitz F, Vivanco JM (2007) Altered profile of secondary metabolites in the root exudates of arabidopsis ATP-binding cassette transporter mutants. Plant Physiol 146:762-771

Bauer BE, Wolfger H, Kuchler K (1999) Inventory and function of yeast $\mathrm{ABC}$ proteins: about sex, stress, pleiotropic drug and heavy metal resistance. Biochim Biophys Acta 1461(2):217-236

Borch K, Bouma TJ, Lynch JP, Brown KM (1999) Ethylene: a regulator of root architectural responses to soil phosphorus availability. Plant, Cell Environ 22:425-431

Campbell EJ, Schenk PM, Kazan K, Penninckx IA, Anderson JP, Maclean DJ, Cammue BP, Ebert PR, Manners JM (2003) Pathogen-responsive expression of a putative ATP-binding cassette transporter gene conferring resistance to the diterpenoid sclareol is regulated by multiple defense signaling pathways in Arabidopsis. Plant Physiol 133:1272-1284

Crouzet J, Trombik T, Fraysse AS, Boutry M (2006) Organization and function of the plant pleiotropic drug resistance $\mathrm{ABC}$ transporter family. FEBS Lett 580:1123-1130

Dassa E, Bouige P (2001) The ABC of ABCs: a phylogenetic and functional classification of $\mathrm{ABC}$ systems in living organisms. Res Microbiol 152(3-4):211-229

Delker C (2006) Jasmonate biosynthesis in arabidopsis thalianaenzymes, products, regulation. Plant Biol (Stuttg) 8(3):297-306

Ducos E, Fraysse S, Boutry M (2005) NtPDR3, an iron-deficiency inducible $\mathrm{ABC}$ transporter in Nicotiana tabacum. FEBS Lett 579:6791-6795
Eichhorn H, Klinghammer M, Becht P, Tenhaken R (2006) Isolation of a novel $\mathrm{ABC}$-transporter gene from soybean induced by salicylic acid. J Exp Bot 57(10):2193-2201

Grec S, Vanham D, de Ribaucourt JC, Purnelle B, Boutry M (2003) Identification of regulatory sequence elements within the transcription promoter region of $\mathrm{NpABC} 1$, a gene encoding a plant $\mathrm{ABC}$ transporter induced by diterpenes. Plant J 35:237-250

Higgins DG, Thompson JD, Gibson TJ (1996) Using CLUSTAL for multiple sequence alignments. Methods Enzymol 266:383-402

Huang S, Li R, Zhang Z, Li L, Gu X, Fan W, Lucas WJ, Wang X, Xie B et al (2009) The genome of the cucumber, Cucumis sativus $\mathrm{L}$. Nat Genet 41:1275-1281

Ito H, Gray WM (2006) A gain-of-function mutation in the Arabidopsis pleiotropic drug resistance transporter PDR9 confers resistance to auxinic herbicides. Plant Physiol 142:63-74

Janda T, Horváth E, Szalai G, PáLdi E (2007) Role of salicylic acid in the induction of abiotic stress tolerance. In: Hayat S, Ahmad A (eds) Salicylic acid—a plant hormone 2007. Springer, Berlin, pp 91-150

Jasinski M, Stukkens Y, Degand H, Purnelle B, Marchand-Brynaert J, Boutry M (2001) A plant plasma membrane ATP binding cassette-type transporter is involved in antifungal terpenoid secretion. Plant Cell 13:1095-1107

Kang J, Hwang JU, Lee M, Kim YY, Assmann SM, Martinoia E, Lee Y (2010) PDR-type ABC transporter mediates cellular uptake of the phytohormone abscisic acid. Proc Natl Acad Sci USA 107(5):2355-2360

Kim DY, Bovet L, Maeshima M, Martinoia E, Lee Y (2007) The ABC transporter AtPDR8 is a cadmium extrusion pump conferring heavy metal resistance. Plant J 50:207-218

Kobae Y, Sekino T, Yoshioka H, Nakagawa T, Martinoia E, Maeshima M (2006) Loss of AtPDR8, a plasma membrane ABC transporter of Arabidopsis thaliana, causes hypersensitive cell death upon pathogen infection. Plant Cell Physiol 47(3): 309-318

Lee M, Lee K, Lee J, Noh EW, Lee Y (2005) AtPDR12 contributes to lead resistance in Arabidopsis. Plant Physiol 138(2):827-836

Migocka M, Papierniak A (2010) Identification of suitable reference genes for studying gene expression in cucumber plants subjected to abiotic stress and growth regulators. Mol Breed 28(3): $343-357$

Moons A (2003) Ospdr9, which encodes a PDR-type ABC transporter, is induced by heavy metals, hypoxic stress and redox perturbations in rice roots. FEBS Lett 553(3):370-376

Moons A (2008) Transcriptional profiling of the PDR gene family in rice roots in response to plant growth regulators, redox perturbations and weak organic acid stresses. Planta 229(1): $53-71$

Rogers B, Decottignies A, Kolaczkowski M, Carvajal E (2001) The pleitropic drug ABC transporters from saccharomyces cerevisiae. J Mol Microbiol Biotechnol 3(2):207-214

Romera FJ, Alcantara E, De la Guardia MD (1999) Ethylene production by $\mathrm{Fe}$-deficient roots and its involvement in the regulation of Fe-deficiency stress responses by strategy in plants. Ann Bot (Lond.) 83:51-55

Růžička K, Strader LC, Bailly A, Yang H, Blakeslee J, Łangowski Ł, Najedla E, Fujita H, Itoh H, Syono K, Hejatko J, Gray WM, Martinoia E, Geisler M, Bartel B, Murphy AS, Friml J (2010) Arabidopsis PIS1 encodes the ABCG37 transporter of auxinic compounds including the auxin precursor indole-3-butyric acid. PNAS 107(23):10749-10753

Salamov AA, Solovyev VV (2000) Ab initio gene finding in Drosophila genomic DNA. Genome Res 10:516-522

Sanchez-Fernandez R, Davies TG, Coleman JO, Rea PA (2001) The Arabidopsis thaliana $\mathrm{ABC}$ protein superfamily, a complete inventory. J Biol Chem 276(32):30231-30244 
Sasabe M, Toyoda K, Shiraishi T, Inagaki Y (2002) cDNA cloning and characterization of tobacco ABC transporter: NtPDR1 is a novel elicitor-responsive gene. FEBS Lett 518(1):164

Shang Y, Xiao J, Ma LL, Wag HY, Qi ZJ, Chen PD, Liu DJ, Wang XE (2009) Characterization of a PDR type ABC transporter gene from wheat (Triticum aestivum L.). Chin Sci Bull 54:3249-3257

Smart CC, Fleming AJ (1996) Hormonal and environmental regulation of a plant PDR5-like ABC transporter. J Biol Chem 271:19351-19357

Sonnhammer ELL, Eddy SR, Birney E, Bateman A, Durbin R (1998) Pfam: multiple sequence alignments and HMM-profiles of protein domain. Nucleic Acids Res 24:17-20

Stein M, Dittgen J, Sanchez-Rodriguez C, Hou BH, Molina A, Schulze-Lefert P, Lipka V, Somerville S (2006) Arabidopsis PEN3/PDR8, an ATP binding cassette transporter, contributes to nonhost resistance to inappropriate pathogens that enter by direct penetration. Plant Cell 18(3):731-746
Strader LC, Bartel B (2009) The Arabidopsis PLEIOTROPIC DRUG RESISTANCE8/ABCG36 ATP binding cassette transporter modulates sensitivity to the auxin precursor indole-3-butyric acid. Plant Cell 21(7):1992-2007

Stukkens Y, Bultreys A, Grec S, Trombik T, Vanham D, Boutry M (2005) NpPDR1, a pleiotropic drug resistance-type ATP-binding cassette transporter from Nicotiana plumbaginifolia, plays a major role in plant pathogen defense. Plant Physiol 139(1): 341-352

Tamura K, Peterson D, Peterson N, Stecher G, Nei M, Kumar S (2011) MEGA5: molecular evolutionary genetics analysis using maximum likelihood, evolutionary distance, and maximum parsimony methods. Mol Biol Evol 28:2731-2739

Trombik T, Jasinski M, Crouzet J, Boutry M (2008) Identification of a cluster IV pleiotropic drug resistance transporter gene expressed in the style of Nicotiana plumbaginifolia. Plant Mol Biol 66:165-175 